\title{
Developing Multicultural Early Childhood Education in a Finnish Context
}

\author{
Mikko Ojala \\ University of Helsinki \\ Finland
}

\begin{abstract}
In this article conditions and activities for developing multicultural educational practices during early childhood education are examined. Within this context, basic ideas for constructing a curriculum, from the national level to the school, teacher and child levels, are described. An important forum for developing educational practices in multicultural education is co-operation with other countries. Theoretical light is shed on the ongoing EU-project INCLUD-ED and recent Finnish experiments and concrete strategies for changing early childhood practices to a more inclusive pedagogy are suggested. Finally, some evaluative comments and questions about fostering multicultural early childhood education in Finland are raised. In this context the important role of early childhood education is recognized as preventing societal and educational exclusion and fostering student's long-term school success.
\end{abstract}

Key words : early childhood education, multicultural education, curriculum, school practices

\section{Introduction}

A multicultural dimension in educational policy is a new aspect of Finnish education. However, because Finland has a growing number of children and parents of multicultural backgrounds, the developmental task in this area is more and more important. The developmental target for multicultural education is especially the capital area of Finland (Helsinki and some smaller cities), where about 40 percent of immigrants live (Ministry of the Interior, 2009). According to estimates, about 25 percent of school children in Finland have

Correspondence concerning this article should be addressed to Mikko Ojala, Professor and Director for Early Childhood Education, Department of Teacher Education (P.O. Box 9) FI-00014, University of Helsinki, Finland. Electronic mail may be sent to mikko.o.ojala@helsinki.fi multicultural backgrounds. This also means an increasing number of children in daycare settings and preschools with such backgrounds.

The main purpose of this article is to describe and evaluate developmental activities for multicultural education in daycare centers and preschools located in the city of Helsinki. A new context for development is based on the European project INCLUD-ED (2006) in which Finland is involved along with other participating countries for a fiveyear period (2007-2011). A special focus in this project is to provide educational strategies and practices for educational and social inclusion. In Finland the focus is on preschools and the transition to primary school.

The main content of this article is as follows. As background, a short introduction is given about the need to develop inclusive education. Thereafter, brief information is provided from the Finnish educational 
policy and curriculum context for Early Childhood Education (ECE). This is followed by presenting some key findings from the development of multicultural education at preschools in Finland and some other countries in the European Union. Evaluative remarks and conclusions are given at the end.

\section{An Inclusive Approach for Developing Multicultural ECE}

Access to quality education has become more and more important in modern society. It is known that the mechanisms of achieving quality education are complicated and value-based (Moss \& Pence, 1994; Ojala, 2004). However, recent findings from the EPPE study in the U.K. show that the quality of the learning environment is perhaps the most important factor in understanding and explaining student learning differences (Siraj-Blatchford, 2006; see also Vandenbroeck, 2007). An even more important finding in this study is that respect for diversity was the most powerful single quality predictor for early learning experiences and later for achievement in school.

The quality of preschools as well as primary schools is important for all students, but especially for children of vulnerable groups, such as migrants, cultural minorities, and those from disadvantaged backgrounds. According to the EPPE Study in the U.K., if children experienced no or poor quality preschool and then moved to a less academically effective primary school, their possibilities for good outcomes were significantly reduced (Sylva, Melhuish, Sammons, Siraj-Blatchford, \& Taggart, 2008). This was particularly the case for those who had already experienced other disadvantages and had a high risk of poor outcomes. For this reason, early learning experiences and educational influences can mitigate or further exacerbate inequalities.

The EPPE study also showed that quality of the home environment was an important factor for children's pre-school and school success, especially for pupils with low SES and varied ethnic status (Sylva et al., 2008). Better quality was achieved when a range of family members provided support for a pupil's learning, pupils themselves were active in maintaining good study habits, and education was valued highly in the family as a means of improving life. Having high expectations for children was found to be important. This can be actualized if parents see education as important for achieving independence and employment opportunities in the future and if they hope that their children can acquire higher education and have a professional career.

However, it is also important to recognize that children's ethnic background is not necessarily an obstacle to school success. The EPPE findings (Sylva et al., 2008) showed that children of Indian heritage could achieve more in mathematics in year 5 than children of white U.K. heritage. However, when English was studied, children with white European heritage scored lower than children of white U.K. heritage. Language acquisition and learning are especially recognized as important tools in educating and schooling children and families from ethnic minority backgrounds. For instance, in a Flemish context, children's language acquisition has been linked to pedagogical methodology (Bennett, Bettens, \& Buysse, 2007). The results showed that open, informal learning with many opportunities for children to participate was the most effective environment for language acquisition.

In a pedagogical context there has been a tendency in recent years to move toward a pedagogy of diversity (Bennett et al., 2007). This covers many aspects, such as gender, a student's cultural and socio-economic background, educational and curricular strategies, children's grouping, and so on. In this pedagogy, the aim is to combine social and educational approaches to assist socially excluded families and children.

There is general agreement that in a knowledgebased society, educational success is crucial to 
overcoming social exclusion. At the European level, school success is defined as a decrease in the dropout rate, the completion of upper secondary education, and participation in secondary education (European Commission, 2000). On the other hand, characteristics of school failure include consistent low achievement or failure to attain the minimum standards of performance, leaving school early or not acquiring the necessary qualifications for the labor market, and the long-term consequences of lacking the skills for successful integration into the labor market (OECD, 1998).

In the recent report Tackling Social and Cultural Inequalities through Early Childhood Education and Care in Europe (2009), the socio-economic environment for children's education and growth was shown to be very important. The report shows abundant evidence that many socio-economic factors can have a significant negative impact on children's development and school success. These factors include poverty, low social class, unskilled and low-paid work, a low aspiration to acquire literacy skills, and a low educational level of the parents. It was estimated that about $17 \%$ of European households with children under the age of six are living on threshold of poverty. Low income or ethnic minority background alone might not be significant, but the combination of these factors can have serious impact on a child's development and learning.

Educational practices can either foster school success or school failure. Current educational practices connected to school failure very often target students from vulnerable groups, such as cultural minorities, migrants, boys, and disabled students. For successful learning, the most critical areas in a knowledge society are associated with mathematics and science, reading, and ICT (INCLUD-ED, 2006).

There are different theoretical approaches to explain why students from vulnerable groups usually demonstrate low educational achievement (INCLUDED, 2008; see also Flecha, 1999). One approach is to understand education as a system for reproducing existing inequalities and social stratification (e.g., Bowles \& Gintis, 1976). In this approach inequalities are analyzed by looking at how schools mirror larger societal inequalities. The reproductionist approach (especially Bourdieu) offers explanations about how cultural capital from family and society determine academic success and later, social activities. As a consequence of this orientation, a good deal of attention has been paid to recognizing diversity among students in relation to their social, cultural and economic backgrounds. However, schools are often not able to pay attention to how inequalities can be effectively eliminated. On the contrary, they often try to use effective segregation practices and reproduce existing inequalities among socio-economic and ethnic groups. This approach ultimately leads to exclusion in education and society.

In yet another approach the main focus is on education and more specifically, on how the educational practice is organized and implemented. In order to escape or reduce segregation, we need to identify which practices increase social exclusion and which ones support and enhance social inclusion. The theoretical orientation adapted in INCLUD-ED (2006) is to look at society as an interaction between systems and agents. Based on several orientations, a number of authors (e.g. Habermas, 1984; Beck, 1992; Giddens, 1984; Beck-Gernsheim, Butler, \& Puigvert, 2003; Bernstein et al., 1997; Willis, 1981; Sen, 1999; Freire, 1998) have argued that in society there are not only structures, but also agents. By activating these agents, we produce existing social stratification, but we are also able to transform the social inequalities. In this view inequalities can be seen as deprivation of freedom to lead one's own life and to take part in crucial decisions about one's life (Sen, 1999). In educational practice, this approach focuses on interactions not only between students and teachers, but also between teachers and students, including peers, parents, administrators, interest groups, community members, and others. This type of pedagogical approach is connected in many ways to 
the work of Vygotsky (1978) and Freire (1998).

In vulnerable groups marginalization is often recognized as a fact. The interactionist view of marginalization is linked to the social context in which educational actions are linked to social actions, such as improving employment, housing, immigration, gender equality, access to health care, and the like. In this context marginalization can be seen as an intermediate position between full integration and social exclusion (Hammer, 2003). Based on this idea, political, social, and cultural dimensions for social exclusion must be considered. When analyzing educational success and failure among vulnerable groups in relation to social cohesion and inclusion, the relationship between education and different areas of society is important.

Some view society as a system in which economy, policy, culture, and societal community can be distinguished as interacting subsystems (Parson, 1977). As a mediator between these subsystems, communication is an important element (e.g., Habermas, 1984). From the communicative perspective, in a societal community people have multiple identities, while at the same time they share a common identity as citizens. For enhancing social cohesion the combination of differences and equality is a fruitful approach.

The role of communication is an important element in educational practice. By using dialogic pedagogy as Freire (1997) suggests or dialogic learning as Flecha (2000) suggests, the school can transform classroom practices by offering dialogic literary gatherings for family members (Soler, 2002). This type of pedagogical practice can foster active participation and their initiates, especially among families with lower educational levels. Communication is also an important mediator when co-operating with different experts and interest groups in education.

\section{A Finnish Context for Developing ECE Practices}

The multicultural ECE is based on national curriculum frameworks. Early childhood education in Finland has two national guidelines. One is based on the National Curriculum Guidelines on Early Childhood Education and Care (ECEC) established in 2004 (National Institute for Health and Welfare, 2004). This is the framework when planning activities for children between the ages of one and five. According to this curriculum, it is important to emphasize the intrinsic value of childhood, to foster childhood, and to help the child develop as a human being (Ojala, Spodek, \& Shirakawa, 2008). In this process, the following goals are considered to be important: (a) promoting personal well-being, (b) reinforcement of considerate behaviors and actions toward others, and (c) a gradual build-up of autonomy.

When implementing the ECEC, the following principles are seen as important:

- The child's well-being as a target,

- Care, education and teaching as an integrated whole,

- The role of educators as a multi-professional educator team (with at least one-third of the staff at the Bachelor's or Master's level),

- The ECEC environment should include physical, psychological and social elements, functional and aesthetic aspects, a positive atmosphere, and promote interactions in different peer groups and small group activities, and

- The joy of learning.

The concept of the acting child is important to keep in mind when implementing curriculum activities. Essential pedagogical tools for acting are play, physical activity, artistic experiences, and selfexpression as well as exploration. The content areas in this curriculum are described by using the term "orientations." These areas are mathematics, the natural sciences, and historical-societal, aesthetic, ethical, and religious-philosophical subjects. By using 
content-specific orientations instead of specific targets in different subjects children's own interests and needs are assumed to be supported as are local circumstances for teaching and learning. In this way, the child does not study or assimilate the content of different orientations or different subjects, and there are no specific performance requirements. The orientations provide educators with a framework that tells them what kinds of experiences, situations, and environments they should look for, give shape to, and offer in order to ensure the children's balanced growth and development. Language is a means of communication and interaction in the context of all orientations. Therefore, it is of vital importance in all care, education, and teaching situations that educators use language that is as careful and accurate as possible, and also that they explain new concepts to children.

The other important pedagogical tool guiding teaching and learning during ECE is the Core Curriculum for Pre-School Education (National Board of Education, 2000). This guideline is planned for children at the age of six, one year before the start of obligatory school.

The following general objectives are seen as important when educating children during the transition from ECE to primary school (Ojala, 2005):

- To promote favorable growth, development, and learning opportunities for children,

- To support and monitor children's physical, psychological, social, cognitive, and emotional development and to prevent any difficulties that may arise,

- To strengthen a healthy sense of self-esteem with the aid of positive learning experiences and provide opportunities for diverse interaction with other children and adults,

- To take into account the special needs of girls and boys,

- To guarantee equal opportunities for children to learn and to start school,

- To strengthen children's positive self-concept and their ability to learn skills,

- To learn the basic skills and knowledge in different areas of learning,

- To learn to understand the significance of a peer group in learning,

- To experience the joy and enthusiasm of learning and to face new learning challenges with courage and creativity,

- To learn how to reflect on what is right and wrong,

- To strengthen and develop children's linguistic and cultural identity and their ability to express themselves, and

- To promote children's interest in nature and an idea of their own independence and responsibility for both nature and the man-made environment.

Even as the importance of theme learning is recognized, there are core subjects identified in the core curriculum. These are (a) language and interaction, (b) mathematics, (c) ethics and philosophy, (d) environmental and natural studies, (e) health, (f) physical and motor development, and (g) art and culture.

The concept of assessment is also recognized in the pre-school core curriculum (Ojala, 2005). On the one hand, assessment is based on the achievement of the core subject objectives. On the other hand, the assessment should be based on the individual growth objectives set in the educational plans made for each child. Assessment is carried out on a continuous basis by means of interaction and discussion between the teacher and the child in the regular learning process. It is important that teachers promote the children's ability assess themselves by supporting the development of the children's self-concepts and the analysis of their own learning. More emphasis in assessment is on the progress of growth and learning than the achievement of objectives.

The construction and implementation of the core curriculum is process oriented. This gives also a variety of possibilities for developing ECE practices 
towards multicultural education. The national core curriculum provides a framework and commitment. Local administrative districts construct a municipal curriculum with local missions. Each pre-school and school has the responsibility to adapt the national and municipal curricula for their school curriculum based on their special needs and interests. Finally, each teacher will transform the school curriculum to learning level of the students:

- The Child's Individual ECEC Plan (for children under six)

- The Child's pre-school educational plan (for sixyear-olds), and

- If needed, an Individual Educational Plan (for children with special needs)

In curriculum construction family participation is important. This is also important when taking into account the opinions multicultural families. The interaction with homes increases a teacher's knowledge about pupils and helps in the planning and carrying out of the teaching. Cooperation between home and school has to be defined in the curriculum as well as cooperation with experts. Family involvement is crucial when working with vulnerable groups (e.g., emigrants' children, children with special needs, and so on).

\section{Findings from the Development of Multicultural Education in Pre-schools}

The findings presented here are based on the INCLUD-ED Project where among other tasks educational processes in local learning projects for preventing inequalities and fostering social and pedagogical inclusion were followed up in Finland, Spain, Cyprus, and Latvia (Ojala, 2008). In this followup pre-schools and schools were chosen based on the following criteria: schools enrolling children with a low socioeconomic (SES) status and a minority background, and which had achieved good academic results in relation to their context. Four different data collection techniques were used: Existing data and documents, open-ended interviews (four students, three family members, three teachers, and other professionals from the school community), a communicative focus group with teachers, and communicative observations. Below, some identified strategies including examples from practices supporting inclusive education are presented.

\section{Opportunities to work together}

Pupils have opportunities to work with children of different age levels (e.g., pre-school age, grades one and two in primary school). In this kind of grouping, children can learn from each other: "For example, in the children's grouping between the pre-school and second class, there are many workshops in which older and younger children work together. So in a way such doctrines help children to learn from each other-younger ones from older ones and vice versa. And this is based on those workshops in which the expert teaches a novice. So children from different age groups study together and learn from each other. It is one way to learn" (the communicative focus group with a Finnish teacher).

\section{Both genders are in balance}

Groups should be balanced according to gender. This type of grouping is an important practice in Finland: "Usually, an attempt is made to divide so that there are as many girls as boys in the classroom" (Finnish teacher of 5 and 6 year olds).

\section{More adults in the classroom}

Providing more adults in the classroom enriches a student's interactions. This type of learning is under study, for example, in Spain. Also in Latvia, the intensive use of human resources is available by using a Roma teacher assistant and a group assistant.

\section{Heterogeneous grouping in terms of ethnic background}

Heterogeneous grouping in terms of ethnic background is widely used in all four countries. In Cyprus, student groups are mixed in terms of gender, 
ethnic background, and learning ability. In this practice students rotate into different groups according to the learning goals in each activity in order to promote the children's initiatives: "It will not be that one group has all the children who need special care and teaching. Likewise, an attempt is made to distribute the immigrant children as evenly as possible" (leader of a daycare center in Finland).

\section{Working in groups with different educational levels}

Working in groups with different educational levels enriches the interaction and education among students. In Spain, this kind of practice promotes solidarity among children during their learning, so that the most disadvantaged students are helped by their classmates and vice versa. Generally, the importance of co-operational learning is recognized as an important practice in Latvia, as well as in Cyprus and Finland: "It does not necessarily have an effect on the progress of others if slow learners are among the others" (a Finnish parent).

\section{Promoting solidarity through instrumental learning}

Promoting solidarity through instrumental learning is used especially in Spain in language and mathematics in heterogeneous groups. Based on these experiences, the idea of helping peers is encouraged.

\section{Offering individual assistance}

Offering individual assistance is widely used in all four countries. This is crucial when working with special needs children and children having ethnic backgrounds. Also when teaching a language, the need for individual assistance is important, not only among children with special needs, but especially among multicultural children in Finland, Cyprus, and Latvia: "And there are these speech therapy groups or others. They are for those children who need help" (a Finnish parent).

\section{Targeted curriculum}

A targeted curriculum for children with special needs is widely used in all four countries. In addition, an individual learning plan is prepared and evaluated for all children in Finland.

Special needs persons available who work with teachers

Special needs persons are available to work with the teachers. This practice is important in Finland, but also in the other three countries: "In the daycare center there can also be a special needs teacher. She will take a child for special support - depending on the child individually or in a group" (a teacher of 5- and 6-yearold children).

\section{Transformative and exclusionary practices are used}

In some cases, both inclusive and exclusionary practices are used. This kind of practice is used in Latvia, for example, where different groups and topics are used with different difficult levels, but with heterogeneous and changing groups.

\section{Expectations}

Expectations play an important role in children's learning and academic success. In Spain, teachers and parents both agreed that it is important to express high expectations of all children. The use of positive communication helps students to create positive attitudes and predispositions to learning. In Cyprus, teachers believed that structural inequalities in society create obstacles, especially for immigrant children. In Latvia, on the other hand, the teachers believed that it is not possible to expect equally good academic results from all children. In Finland, equal opportunity for learning and development is one of the most important educational policies in preprimary education and later schooling.

\section{Conclusions}

The Finnish early childhood context has many characteristics that make it possible to develop and 
implement an inclusive ECE. Teacher training for the pre-primary level is integrated into university training. A leading principle in this training is to develop educators who are ready to develop their practices and can reflect on their work at a more theoretical level. The profession of ECE is also very attractive, and only the best students are accepted into the training program (the acceptance rate is about $16 \%$ of all applicants yearly). Also the curriculum content has many positive aspects for supporting inclusion. The curriculum evaluates children as active learners. The process orientation of teaching and learning is highly valued. Every teacher must actively construct the curriculum for each child's individual learning plan.

If needed, special support for children is available and helps teachers, children, and parents to understand and support the children's learning. And when children move to primary school, the general conditions for inclusive practices are also good. When studying at comprehensive schools in Finland, the drop-out rate among students has been less than $1 \%$. In primary education (the years from seven to 16 ), students' learning is carefully followed and also evaluated at the individual level. And if needed, many kinds of support are given, especially for students at risk. If needed, students can continue their learning an extra year after the required schooling (the so-called 10th class).

As shown in this short comparative analysis of inclusive school practices in Finland, Spain, Cyprus, and Latvia, we have encouraging new ideas for developing our multicultural ECE. One interesting finding comes from Spain. When developing inclusive practices, the Spanish have very attractive experiences in using interactive groups (e.g. Flecha, 2000). According to findings in the INCLUD-ED project, cooperative and interactive work with peers makes a positive contribution to academic achievement. As Vygotsky (1978) has also proposed, children learn better when they interact with adults or with more capable peers. According to Spanish experiences involving adults, such as family members and volunteers, in instrumental learning in the classroom activities, we can promote a greater number of interactions and in this way benefit the learning process, as well as provide positive role models for social groups inside the school.

The leading idea in interactive groups is to help children with their interactions with peers in heterogeneous groups (Soler, 2004). This involves various groups learning together in a heterogeneous way (in terms of gender, culture, educational level, and special needs) and carrying out different activities for the duration of the class. Each group is supported by an adult, either a volunteer or a teacher. It allows all the students to attend and provides a wide and rich range of interactions with adults and more opportunities to learn through dialogue. It also allows several activities to be carried out in one class. It generates more motivation and concentration on children's activities. Students with more difficulties can engage in the same activities as the rest of the class in normal conditions. And finally, it can contribute to better coexistence among classmates and to better behavior in class in relation to such things as solidarity and cooperative relationships.

Perhaps when the Finnish inclusive practice is better developed, we might also have access to the many positive consequences characteristic of the Spanish examples. For now, in my experience, the Finnish ECE and school practice do not use many parent or other adult volunteers in educational practices. Perhaps this is an especially important strategy in multi-cultural education.

When developing a multicultural education in ECE, we recognize a rich variety of tasks. But it is impossible to change all of these at the same time. For this reason it is perhaps better to concentrate first on just some of those. This was the strategy in our recent developmental project implemented at four daycare centers in the city of Helsinki (Kuusisto, 2010). In this project the developmental activities in multicultural ECE were focused on four key elements: values, the 
learning environment, the support of children's growth and development, and cooperation and support for parents.

When working and developing ECE, we must always understand that the pre-primary education plays a crucial role in preventing societal and educational exclusion and fostering student's longterm school success. Cunha and Nobel prize-winner, Heckman, an economist, suggest that the early childhood period gives the best opportunity for investment in human capital in relation to later opportunities during schooling at the primary and secondary levels (Cunha, Heckman, Lochner, \& Masterov, 2005; see also OECD, 2006). This happens because learning at one stage begets learning in the next. For this reason learning in early childhood is especially important. Where human capital is concerned, the authors conclude that the rate of return on one dollar of investment made during a child's early years is greater than an investment of the same sum later. Positive or negative dispositions toward society and learning are absorbed and basic life skills acquired. According to Cunha et. al. (2005), important basic life skills are cooperation with peers and adults, autonomy, meaning making, creativity, problem solving, and persistence.

\section{References}

Beck, U. (1992). Risk society. New York: Sage.

Beck-Gernsheim, E., Butler, J., \& Puigvert, L. (2003). Women and social transformation. New York: Peter Lang.

Bennett, J., Bettens, C., \& Buysse, B. (2007, June). Policy on diversity and social inclusion in early childhood education and care. Report on the 1st OECD Starting Strong Network workshop. Brussels, Belgium.

Bowles, S., \& Gintis, H. (1976). Schooling in capitalistic America: Educational reform and the contradictions of economic life. New York: Basic Books.
Cunha, F.J., Heckman, J., Lochner, L., \& Masterov, D. V. (2005, July). Interpreting the evidence of life-cycle skills formation (IZA Discussion Papers No. 1575). Bonn, Germany: Institute for the Study of Labour. Education, Audiovisual and Cultural Executive Agency P9 Eurydice. (2009). Tackling social and cultural inequalities through early childhood education and care in Europe. Brussels: Author.

Giddens, A. (1984). The constitution of society: Outline of the theory of structuration. Berkeley: University of California Press.

Flecha, R. (1999). New educational inequalities. In M. Castells, P. Freire, R. Flecha, H. Giroux, D. Macedo, \& P. Willis. Critical Education in the New Information Age. Lanham, MD: Rowman \& Littlefield.

Flecha, R. (2000). Sharing Words: Theory and practice of dialogic learning. Lanham, MD: Rowman \& Littlefield.

Freire, P. (1997). Pedagogy of the heart. New York: The Continuum.

Freire, P. (1998). Pedagogy of freedom: Ethics, democracy and civil courage. Lanham, MD: Rowman \& Littlefield.

Habermas, J. (1984). The theory of communicative action: Reason and the rationalization of society(Vol. 1). Boston, MA: Beacon Press.

Hammer, T. (2003). Youth unemployment and social exclusion in Europe: A comparative study. Bristol: Policy Press.

INCLUD-ED. (2006). Strategies for inclusion and social cohesion in Europe from education. Sixth Framework Programme. Priority 7. Citizens and governance in a knowledge-based society. Integrated project.

INCLUD-ED. (2008). Theories, reforms, and outcomes in the European education systems. Report 2, WP 4. University of Barcelona: CREA.

Kuusisto, A. (2010). Kulttuurinen, kielellinen ja katsomuksellinen monimuotoisuus päiväkodissa: Haasteita ja mahdollisuuksia [Cultural, linguistic and ideological diversity in daycare center: 
Challenges and possibilities]. Helsingin kaupungin sosiaalivirasto: Tutkimuksia.

Ministry of the Interior. (2009). Monitori: Tilastoliite /Statistics. Retrieved February 22, 2009, from http://www.intermin.fi/maahanmuutto.

Moss, P. \& Pence, A. (Eds.). (1994). Valuating quality in early childhood services. London: Paul Chapman.

National Board of Education. (2000). Core curriculum for pre-school education in Finland. Helsinki: National Board of Education.

National Institute for Health and Welfare. (2004). National curriculum guidelines on early childhood education and care(ECEC). Helsinki: National Institute for Health and Welfare.

OECD. (1998). Overcoming failure at school. Paris: Author.

OECD. (2006). Starting Strong II: Early childhood education and care. Paris: Author.

Ojala, M. (2004). Looking for quality in early childhood education. In M. Lundqvist \& C. Öhberg. Det synliga barnet. Praktiska och teoretiska perspective på pedagogiken (pp.131-140). Rapport från Pedagogiska fakulteten vid Åbo Akademi, 9 . Turku: Åbo Akademi.

Ojala, M. (2005). How Finland is researching early childhood education. In B. Spodek \& O. N. Saracho (Eds.) International perspectives on research in early childhood education (pp. 79-118). Information Age Publishing: Greenwich, Connecticut.

Ojala, M. (2008). Cross-case comparative analysis for preprimary schools. INCLUD-ED. Project 2: European effective educational practices: How is education contributing to overcome or reproduce social exclusion? Helsinki, Finland: University of Helsinki, Department of Behavioural Sciences.

Ojala M., Spodek, B., \& Shirakawa, Y. (2008) Educational reform and child raising in Finland. International Center for Child Studies, 10. Japan: Konan Women's University, Center for Child Studies.
Sen, A. (1999). Inequality re-examined. New YorkCambridge: Russel Sage Foundation \& Harvard University.

Siraj-Blatchford, I. (2006, October). The impact of early childhood settings and families on children's development. Paper presented at the Promoting diversity through education, Bratislava, Slovakia.

Soler, M. (2002, April). Dialogic reading: Adult learners crossing cultural borders. Paper presented at the annual meeting of the American Research Association. New Orleans, LA.

Soler-Gallart, M. (2004). Dialogic education: Schools in Spain today. Networks, an On-line Journal for Teacher Research, 7(1). Retrieved March, 26, 2010, from http://journals.library.wisc.edu/index.php / networks/issue/view/5

Sylva, K., Melhuish, E., Sammons, P., Siraj-Blatchford, I., \& Taggart, B. (2008). Effective pre-school and primary education 3-11 project (EPPE 3-11): Final report from the primary Phase: Preschool, school and family influences on children's development during key stage 2 (ages 7-11) (Research report DCSFRRO61). Nottingham, United Kingdom: Great Britain, Department for Children, Schools and Families.

Vandenbroeck, M. (2007). Beyond anti-bias education: changing conceptions of diversity and equity in European early childhood education. European Early Childhood Education Research Journal, 15(1), 21-35.

Vygotsky, L. (1978). Mind of society. Cambridge, MA: Harvard University Press.

Willis, P. E. (1981). Learning to labour. How working class kids get working jobs. Aldershot: Gower. 